\title{
WARIANTYWNOŚĆ (ORTO)GRAFICZNA POŻYCZEK ANGIELSKICH W ŚWIETLE NORMATYWISTYKI JĘZYKA ROSYJSKIEGO
}

\author{
(ORTHO)GRAPHIC VARIANTS OF ENGLISH LOANWORDS \\ BASED ON THE LINGUISTIC STANDARD OF RUSSIAN
}

\author{
ANNA ROMANIK
}

\begin{abstract}
AвSTRACT. The article focuses on the problem of orthographic and graphic variants of English loanwords in modern Russian. The empirical material was excerpted from normative dictionaries and Russian glossy magazines. The main purpose of the studies was to define the reasons for different notation of anglicisms, to illustrate the types of orthographic and graphic variants, and also to indicate the most important issues of loanword codification in normative practice. Variation in writing is a dynamic phenomenon in Russian (ortho) graphy that requires lexicographical description as there are no separate rules of notation for loanwords.
\end{abstract}

Keywords: codification, English loanwords, linguistic standard, (ortho)graphic variants, Russian language

Anna Romanik, Uniwersytet w Białymstoku, Białystok - Polska, aniaromanik8@wp.pl

ORCID ID: 0000-0002-2733-6503

\section{Słowo wstępu}

Pożyczki angielskie we współczesnym języku rosyjskim stanowią obiekt zainteresowania wielu lingwistów. Zagadnienie transferu leksykalnego z obcych systemów językowych jest przedstawiane z różnych perspektyw badawczych, co zresztą nie dziwi, ponieważ proces zapożyczania to zjawisko złożone, wymagające wieloaspektowych analiz. Poza tym permanentny import pożyczek zachodzi praktycznie na naszych oczach i między innymi z tego powodu wymaga nieustannych komentarzy. Przejmowanie anglicyzmów na grunt rosyjski rodzi pewne konsekwencje, które w istotnej mierze rzutują na obecny stan współczesnego języka rosyjskiego, w związku z tym kontynuacja analizy procesu zapożyczania okazuje się wręcz konieczna.

Przedmiotem niniejszych rozważań jest wariantywność ortograficzna i graficzna anglicyzmów we współczesnym języku rosyjskim. Podjęta problematyka staje się pretekstem do poruszenia jeszcze jednej niezwykle ważnej kwestii, a mianowicie problemu kodyfikacji zapożyczeń w normie języka rosyjskiego. Celem publikacji jest wskazanie przyczyn braku jednolitej notacji 
grupy anglicyzmów w wybranych rosyjskich tekstach pisanych, zilustrowanie egzemplifikacyjne wariantów (orto)graficznych oraz wskazanie konsekwencji danego zjawiska w świetle normatywistyki współczesnego języka rosyjskiego. Materiał empiryczny został wyekscerpowany z rosyjskojęzycznych czasopism (, Cosmopolitan", , Cosmopolitan Shopping", ,"ELLE”, ,"Glamour", „Vogue”, „Красота и здоровье”, „Люблюlife”, „Мы женимся”), opublikowanych w latach 2016-2017, a także ze słowników wyrazów obcych, które rejestrują najnowsze zapożyczenia funkcjonujące $\mathrm{w}$ mass mediach ${ }^{1}$. Wybór wskazanych periodyków nie był przypadkowy. Panuje bowiem przekonanie, że obecnie to prasa, w tym czasopisma oraz inne media, sankcjonuje (wydaje się, że w sposób zupełnie niekontrolowany) normy językowe, powoli odbierając ten przywilej literaturze pięknej. Niejednokrotnie słyszy się pejoratywne opinie o języku w mediach, niemniej jednak nie należy lekceważyć wpływu mediów na stan współczesnych języków narodowych. Jak słusznie zauważa Stanisław Gajda, media „zmieniają rolę i kształt tradycyjnych postaci istnienia języka, tj. mowy ustnej, pisma i druku" [Gajda 2000: 19].

Do analizy problemu kodyfikacji wariantów ortograficznych najnowszych anglicyzmów został wykorzystany słownik ortograficzny zredagowany przez członków Rosyjskiej Akademii Nauk [Лопатин, Иванова 2016].

\section{Warianty (orto)graficzne pożyczek angielskich we współczesnych czasopismach rosyjskich}

Problem wariantywności zarówno ortograficznej, jak i graficznej anglicyzmów zaczerpniętych z języka massmediów wymaga szczególnej uwagi, ponieważ zjawisko paraleli językowych staje się coraz bardziej powszechne. Może to budzić pewien niepokój lingwistów, a także przeciętnego użytkownika języka, gdyż pojawiają się trudności w ustaleniu względnie jednolitej zasady ortograficznej, która ułatwiałaby poprawne posługiwanie językiem w piśmie. Nina Wałgina zauważa, że obecność wariantów w języku generuje wyraźne problemy normy językowej, lecz dodaje jednocześnie, że „изучение конкуренции вариантов является важным этапом в определении тенденций в развитии языка, в определении живых активных процессов в языке" [Валгина 2003: 40].

Termin wariant językowy w lingwistyce nie doczekał się jednoznacznej definicji. Warto posłużyć się w tym miejscu zwięzłym określeniem wariantu przytaczanym przez Andrzeja Markowskiego. Według badacza warianty językowe to istniejące w normie środki oboczne, równoległe, pełniące w zasadzie

\footnotetext{
${ }^{1}$ Dane bibliograficzne wydawnictw leksykograficznych znajdują się na końcu artykułu.
} 
tę samą funkcję [Markowski 2005: 37]. Natomiast wspomniana już Wałgina, definiując znaczenie wariantu, podkreśla, że jest to formalna wersja słowa (tożsama z danym słowem), która posiada dokładnie takie samo znaczenie, a także strukturę morfologiczną [Валгина 2003: 29].

W opinii jednego z czołowych normatywistów rosyjskich Kiriłła Gorbaczewicza paralele $\mathrm{w}$ języku były i są zjawiskiem powszechnym, a nawet charakterystycznym dla żywego języka literackiego [Горбачевич 1978: 28]. Zwraca on uwagę na liczne głosy negatywnie oceniające istnienie różnego rodzaju dubletów w języku, uznające je za bolączkę systemu i wzywające językoznawców do określenia restrykcyjnych zasad, które mogłyby wyeliminować z języka kłopotliwe niekiedy warianty. Niemniej sam Gorbaczewicz podkreśla, że takie poglądy są błędne, ponieważ wariantywność należy w zasadzie uznać za pozytywne zjawisko będące żywym dowodem rozwoju języka. Badacz konsekwentnie twierdzi, że „варьирование формы - это объективное и неизбежное следствие языковой эволюции" [Горбачевич 1978: 29].

Wśród pożyczek angielskich spotykanych na łamach czasopism zjawisko wariantywności ortograficznej jest wyraźnie dostrzegalne. Dotyczy to przede wszystkim neologizmów, których żywotność w nowym systemie językowym jest, relatywnie rzecz ujmując, krótka. W zgromadzonym materiale znalazły się zatem zarówno leksemy, których obecność poświadczono w słownikach, jak i jednostki leksykalne nienotowane jeszcze w zbiorach leksykograficznych. W literaturze przedmiotu nie ma wprawdzie dla nich odrębnego ogólnie przyjętego terminu, ale takie wyrazy nieposiadające notacji słownikowej Teresa Smółkowa proponuje określać mianem neologizmów tekstowych lub innowacji tekstowych [Smółkowa 2000: 68].

W wielu przypadkach wspólistnienie różnych wersji zapisu tego samego anglicyzmu wynika z faktu, że przedostają się one do języka w sposób niekontrolowany i dynamiczny, co właśnie skutkuje powstawaniem form alternatywnych. Angielski zyskał rangę języka międzynarodowego i posługuje się nim coraz większa liczba Rosjan. Wysokie tempo upowszechniania się zapożyczeń przekłada się na pewnego rodzaju chaos komunikacyjny, który jest charakterystyczny dla początkowego etapu transferu leksykalnego. Niemniej jednak język w toku ewolucji dokonuje uporządkowania i regulacji, tzn. normalizuje, kodyfikuje innowacje, dopasowując je do trwałego systemu językowego.

Z obserwacji badanych źródeł wynika, że wśród zaświadczonych $w$ nich paraleli ortograficznych istotne miejsce zajmują złożenia składające się z dwóch obcojęzycznych członów oraz konstrukcje złożone z pierwszym elementem obcym. Ich kształt graficzny nie jest ustabilizowany. $W$ tekstach spotkać można warianty tej samej jednostki pisanej łącznie lub z dywizem, 
a nawet rozdzielnie, np. бигфут / биг-фут, бизнесвумен / бизнес-вумен, бизнеследи / бизнес-леди, саундтрек / саунд-трек, стритстайл / стрит-стайл, фееисконтроль / фейс-конттроль.

Niektórym pożyczkom warto przyjrzeć się dokładniej. Ciekawym przypadkiem jest neologizm антиэйдж / анти-эйдж, który na łamach czasopism można spotkać w przeróżnych konfiguracjach graficznych, bowiem zarejestrowano złożenia $\mathrm{z}$ tym elementem pisane łącznie, $\mathrm{z}$ dywizem lub osobno. Poza tym na równi z zapisem cyrylicą funkcjonują paralele w grafii łacińskiej, tworzące niekiedy interesujące struktury hybrydalne. Ilustracją danej wariacji są następujące cytaty przedstawiające formę ekwiwalentu ortograficznego i jego użycie w tekście: Современные возможности антиэйдж-медицины должны обязательно использоваться наряду с косметическим уходом и косметологическими процедурами [„ККрасота и здоровье”, май № 5 (206) 2017: 68]; Дорина Донич, д.м.н., специалист В области биорепаративной и anti-age медицины [„Красота и здоровье”, май № 5 (206) 2017: 52]; С такого массажа обычно начинают знакомство с аппаратными anti-age-процедурами [„,Соsmopolitan”, июнь 2017: 90]; Уникальная технология молекулярного фракционирования позволила получить эти природные, невоссоздаваемые искусственным путём anti-age-компоненты, абсолютно биосовместимые с клетками кожи [„Glamour", май 2017: 123]; ...говорит Марина Рябус, к.м.н., спеизиалист по антивозрастной медицине и основатель именной антиэйдж-клиники [„Cosmopolitan”, июнь 2017: 90].

Należy także zaznaczyć, że nieustabilizowana pisownia pożyczek (łączna, z dywizem lub rozdzielna) czasami jest zupełnie przypadkowa, świadczy o krótkiej obecności wyrazu w języku rosyjskim lub po prostu jest wynikiem błędu. Za takie właśnie „niedopatrzenie” można uznać leksem диджей, który w słownikach funkcjonuje $\mathrm{w}$ zapisie łącznym, natomiast $\mathrm{w}$ badanych periodykach zarejestrowano jego wariacje: Карина. Активная ведущая, томада для свадеб, юбилеев и корпоративов, ди-джей, фото-видео [„Мы женимся”, август - сентябрь 2017 (54) 4: 65]; Жемчужина в короне Black Star - Кристина Си, отвечала за музыкальную часть вечера наряду с диджеем Tanya Darguzhas ["Glamour", июль 2017: 31]. Z drugiej strony, odmienne zapisy tego samego wyrazu mogą wynikać z różnej jego semantyki. Należy wówczas zachować ostrożność, ponieważ takich paraleli leksykalnych nie można uznać za warianty językowe. Nie spełniają one bowiem jednego z podstawowych warunków wynikających z definicji wariantu, gdyż posiadają odmienne znaczenia. Za przykład mogą posłużyć leksemy фpacm-фpyd i фрacmфyd. Jekatierina Szagałowa w swoim słowniku wyrazów obcych wskazuje na semantyczne różnice między tymi wyrazami i właśnie od znaczenia uzależnia ich pisownię. Zgodnie z definicją słownikową фpacm-фbyd (pisownia z łącznikiem) oznacza restaurację, kawiarnię nastawioną na szybką obsługę klienta, a dpacmøyd (pi- 
sownia łączna) nazywa szybkie jedzenie, tj. hamburgery, pizzę itd. [Шагалова 2017: 477]. W badanych tekstach czasopism rozgraniczenia semantyczne, od których Szagałowa uzależnia pisownię, rzeczywiście są ewidentne: И это не дешеёый фаст-фуд: официант с бабочкой, белые скатерти, безупречная чистота, а от запаха крышу сносит [„Люблюlife”, май-июнь 2017: 108]; Нет - фастфруду, да - спорту и правильным бъюти-средствам ["Glamour", май 2017: 30, 190].

Kolejną wariacją natury ortograficznej odnotowaną wśród badanych anglicyzmów jest wymienna pisownia samogłosek э oraz e dla realizacji tego samego fonemu angielskiego, np. бэкграунд / бекграунд, печворк / пэчворк, скребл / скрэббл, снек-бар / снэк-бар, фрлешбек / флеш-бэк, хендлер / хэндлер, хештег / хэштег.

$\mathrm{W}$ analizowanych periodykach, które tematycznie związane są z modą, jaskrawym przykładem ekwiwalentów ortograficznych omawianego typu jest odznaczający się wysoką frekwencją anglicyzm фэшн / фешен. Dana jednostka rzadko występuje samodzielnie jako wyraz prosty, zazwyczaj stanowi część składową struktur złożonych, nр.: Линда Тол, блогер из Амстердама, сотрудничает со многими фрешен- и бъюти-компаниями ["Cosmopolitan”, июль 2017: 57]; Фешен-этюд в бежевых тонах [„Cosmopolitan”, июнь 2017: 12]; Самая модная девушка Варшавы, фээнн-блогер Джессика Мерседес славит местные бренды и учит своих поклонников есть овсянку по утрам [„Vogue”, май 2017: 23]; Давно хочу сказать спасибо редакции за фрэшн-истории с моделями plus-size, апрельская съёмка $b$ нижнем белье - это вообще настоящая бомба! ["Glamour", май 2017: 124].

Na łamach czasopism nie brakuje innych wariantów z wymienną pisownią samogłosek: Из этих ребят получился бы отличный бойз-бенд, но и соло они вполне убедительны [„Glamour", октябрь 2016: 37]; Зато Кристина точно знает, чего хочет: „Живые музыканты, свой бэнд - вот моя мечта" [„Glamour", июль 2017: 24]; Символ Любви и Статую Счастья снимите это на камеры и разместите в соисетях под хештегом „свадьбы" [„Мы женимся", август - сентябрь 2017 (54) 4: 54]; Вкладывай $b$ Instagram с хэштегом \#соsmopolitanshoppingstyle и следи за публикациями ["Cosmopolitan Shopping", июль - август 2017: 14].

Wśród anglicyzmów funkcjonujących we współczesnych rosyjskich periodykach obserwuje się także niestabilną pisownię pojedynczych lub podwójnych spółgłosek, np. билборд / билборд, стаффр / стаф, треккинг / трекинг. Poza tym ekwiwalencja ortograficzna jest zauważalna $w$ pisowni wielkiej i małej litery (Инстаграм / инстаграм, Интернет / интернет).

Warto zwrócić uwagę na jeszcze jedną bardzo istotną w badanym kontekście kwestię - mianowicie na temat wariantywności graficznej zapożyczeń angielskich, dość licznie reprezentowanych w dyskursie czasopiśmienniczym. Wprawdzie grafia stanowi odrębny obszar systemu językowego, 
niemniej jednak w sposób istotny łączy się z ortografią i, co najważniejsze, zmiany natury graficznej znacząco wpływają na pisownię języka, a w konsekwencji także na regulacje ortograficzne.

Wariacje graficzne polegają na zapisie anglicyzmów przy użyciu dwóch alfabetów, cyrylicy i łacinki. Za przykład mogą posłużyć następujące paralele leksykalne: айфон / iPhone, антиэйдж/анти-эйдж/anti-age, гламyp / glamour, мейкаn / make-ир, плюс-сайз/plus size, стритстайл/стрит-стайл/street style, фейсбук / Facebook, фешен / фәэн / fashion.

Wtręty pisane łacinką $\mathrm{w}$ tekstach rosyjskich cieszą się dużą frekwencją między innymi ze względu na swoją wizualną odmienność. Ich wyrazistość widać szczególnie $\mathrm{w}$ porównaniu z wersją anglicyzmu w pełni zaadaptowanego w grafii rosyjskiej, np.: Сейчас многие насмотрятся в Instagram картиноки начинают колоть губы, резать носы, чтобы подогнать себя под интернет-стандарты [„Cosmopolitan”, июль 2017: 25]; В Век инстаграма и торжества соисетей 8 Доме Geurlain больще года хранили в тайне имя новой посланницы марки - Анджелины Джоли [„Glamour”, май 2017: 94]; Beauty-редактор „КE3” Анастасия Миронова рассказывает о фаворитах месяца, которые не оставили ее равнодушной и могут стать вашими новыми любимиами [„,Красота и здоровье", май № 5 (206) 2017: 24]; 2017 год начался со знакового события в бъюти-индустрии [„Красота и здоровье”, май № 5 (206) 2017: 49].

Przytoczone przykłady wariantów graficznych ilustrują ogólne tendencje rozwojowe współczesnego języka prasy rosyjskiej. Przypadki użycia odmiennej grafii mają swoje uzasadnienie zarówno natury językowej, jak i pozajęzykowej. Fakt ten można wytłumaczyć zrozumiałą potrzebą precyzji semantycznej z jednej strony, z drugiej zaś, swoistą potrzebą stylizacji tekstu nastawionej na jego okcydentalizację, co można uznać za w pełni świadomą strategię stosowaną przez autorów teksów prasowych w celach manipulacyjnych. Z kolei Mirosław Bańko i Milena Hebal-Jezierska warianty graficzne o wyrazistych znamionach obcości określają jako elementy erudycyjne i dodają, że w odczuciu społecznym są one często postrzegane jako te lepsze [Bańko, Hebal-Jezierska 2015: 159]. Jednak niezależnie od potencjalnych przyczyn pojawiania się w języku rosyjskim anglicyzmów $\mathrm{w}$ alfabecie łacińskim są one faktem lingwistycznym, który z punktu widzenia zadań współczesnej normatywistyki stanowi istotny problem standaryzacji normy języka w ujęciu systemowym.

\section{Norma językowa wobec wariacji (orto)graficznych zapożyczeń}

Zjawisko wariantywności ortograficznej pożyczek angielskich we współczesnej ruszczyźnie, które permanentnie odnotowuje się na łamach czasopism, generuje problemy $\mathrm{w}$ obszarze normy językowej. Z socjolingwistycznego 
punktu widzenia jest to bardzo ciekawe zagadnienie, tym bardziej, że omawiany materiał pochodzi z najnowszego okresu i tym samym jest sporym wyzwaniem dla badaczy języka i przede wszystkim dla normatywistów.

Podejmując temat normy językowej, należy zachować dużą ostrożność ze względu na mnogość interpretacji tego terminu [Bugajski 1993: 87]. Istnieją też różne klasyfikacje normy, zresztą samo pojęcie ewoluowało na przestrzeni wielu lat. Warto odwołać się do definicji, które istotnie korelują z niniejszymi rozważaniami. Zgodnie z opisem słownikowym rozumiana bardzo szeroko norma to „принятое речевое употребление языковых средств, совокупность правил (регламентаций), упорядочивающих употребление языковых средств в речи индивида" [Ахманова 2016: 270]. W literaturze przedmiotu pojawia się słuszne rozgraniczenie „normy użytkowej” od „normy skodyfikowanej". Ciekawe rozumienie tych pojęć proponuje Andrzej Markowski. Wprawdzie odnosi się ono do polszczyzny, niemniej jednak ma charakter uniwersalny i w kontekście podjętego tematu, mówiąc o języku rosyjskim, jest jak najbardziej adekwatne. Według badacza „norma skodyfikowana jest kształtowana $\mathrm{z}$ udziałem refleksji językowej i świadomego odwoływania się do tradycji oraz znajomości systemu językowego. Jest to norma ujęta w opisy, przepisy i wzory" [Markowski 2011: 30]. Natomiast norma użytkowa "obejmuje zbiór wyrazów, ich form i połączeń, używanych w kontaktach swobodnych, nieoficjalnych, o różnorodnej tematyce. Chodzi więc o zespół środków językowych charakterystycznych przede wszystkim dla typów kontaktów, w których język traktuje się jako narzędzie przekazu informacji, perswazji itd." [Markowski 2011: 34]. Elementy języka uznane za normę użytkową wcale nie muszą być zgodne z tradycją czy też systemem językowym. Są one rozpowszechniane ze względu na swój potencjał komunikacyjny, co oznacza, że charakteryzują się wyrazistością, ekonomicznością, istotną wartością użytkową. Zatem powyżej przytoczone przykłady paraleli ortograficznych i graficznych anglicyzmów odnotowanych we współczesnych czasopismach rosyjskich stanowią przykład elementów języka reprezentującego normę użytkową. Natomiast bardzo ciekawą kwestią jest to, w jaki sposób badane zapożyczenia sankcjonuje norma wzorcowa, a ściślej mówiąc, jak wygląda dziś oficjalna kodyfikacja tych form.

Kodyfikacja normy językowej wiąże się z działalnością normalizatorską zarówno uprawomocnionych do tego zadania instytucji, jak i reprezentujących je osób i ma na celu arbitralne ujednolicenie reguł pisowni, między innymi omawianych zapożyczeń, stworzenie całego systemu zasad i rekomendacji. W Rosji kodyfikacją norm językowych oficjalnie zajmują się członkowie i pracownicy konkretnych czterech jednostek o charakterze oświatowo-naukowym. Są to czołowe ośrodki uniwersyteckie i instytucje naukowe, które zostały wskazane i tym samym upoważnione do takiej działalności na 
mocy Rozporządzenia Ministerstwa Edukacji i Nauki Federacji Rosyjskiej z dnia 29 grudnia 2008 roku². Zatem za wzór ortograficznej normy językowej należy przyjąć wersje słownikowe rekomendowane przez ww. autorytety.

Wybór publikacji leksykograficznych posiadających wzorcotwórczy przywilej, działających jak "filtr językowy” [Горбачевич 1978: 26] jest stosunkowo obszerny, ale należy zaznaczyć, że zawarte w nich rekomendacje wcale nie są jednolite. Dotyczy to także problemu wariantywności zapożyczeń. Słowniki niekiedy odmiennie standaryzują zapis poprawnościowy neologizmów, dlatego też z metodologicznego punktu widzenia sensowny wydaje się wybór jednego autorytetu. W przypadku niniejszych rozważań jest to już wсześniej wspomniany Русский орфографический словарь [Лопатин, Иванова 2016], rekomendowany przez Instytut Języka Rosyjskiego im. W. W. Winogradowa Rosyjskiej Akademii Nauk. Z analizy materiałów normatywnych wynika, że dana pozycja reprezentuje najbardziej restrykcyjne podejście wobec wariantów ortograficznych. Autorzy tego najobszerniejszego jak dotąd normatywnego słownika ortograficznego twierdzą, że z pragmatycznego punktu widzenia przedłożony użytkownikom języka słownik (wcześniejsze jego wydania) i wzorce w nich zawarte w zauważalny sposób kreują standardy językowe w piśmie. We wstępie do swojego leksykograficznego kompendium piszą: „И нельзя не отметить, что в практике письма (прежде всего в средствах массовой информации) написания, основывающиеся на данных рекомендациях, за прошедшие годы стали преобладающими, закрепились" [Лопатин, Иванова 2016: III]. Proces regulacji zasad pisowni elementów zapożyczonych oraz ich kodyfikacji, która ułatwia posługiwanie się poprawną ruszczyzną, jest bardzo istotnym końcowym etapem adaptacji anglicyzmów w systemie języka.

Bazując na wskazanym słowniku, warto przyjrzeć się, w jaki sposób problem wariantywności ortograficznej anglojęzycznych jednostek jest regulowany przez normy języka rosyjskiego. Na podstawie przeprowadzonych obserwacji można stwierdzić, że współczesna norma dąży do eliminacji wariantów ortograficznych jednostek obcej proweniencji, co nie oznacza w żadnym wypadku ich całkowitej eliminacji. Autorzy słownika w wielu przypadkach ewidentnie dokonują wyboru jednego zalecanego zapisu przytaczanych wcześniej wariantów anglicyzmów. Rzecz jasna, nie dotyczy to neologizmów tekstowych,

${ }^{2}$ W Rozporządzeniu Ministerstwa Edukacji i Nauki Federacji Rosyjskiej z dnia 29 grudnia 2008 roku wskazano uczelnie wyższe oraz inne organizacje, które uprawomocniono do przeprowadzania ekspertyz z zakresu gramatyki rosyjskiej, słowników oraz poradników formułujących normy literackie języka rosyjskiego jako państwowego języka Federacji Rosyjskiej. Na liście znalazły się następujące gremia: Институт русского языка им. В. В. Виноградова Российской академии наук, Государственный институт русского языка им. А. С. Пушкина, Московский государственный университет им. М. В. Ломоносова, Санкт-Петербургский государственный университет. 
które nie mają poświadczeń leksykograficznych, bowiem funkcjonują jedynie w przestrzeni czasopiśmienniczej. Niemniej jednak w odniesieniu do większości notowanych leksemów można dostrzec kategoryczne rozstrzygnięcia ortograficzne. Na przykład zaleca się pisownię z dywizem słowa бизнес-леди, natomiast łączną pisownię leksemów бизнесbумен, диджей, саундтрек, стритстайл, фейсконтроль, a także фастфууд, w którym nie uwzględnia się jego zróżnicowania semantycznego. Poza tym w przypadku większości omawianych wcześniej dubletów ortograficznych przedstawiających wariacje samogłoskowe, głównie opozycję e-э, słownik również utrwala konkretny zapis. Leksemy бэкграунд сzy też флешбэк są zapisane z samogłoską э, ale leksemy хендлер, бенд, скребл, фешен, хендлер zaleca się pisać z samogłoską e. Natomiast dla wielu odnotowanych $\mathrm{w}$ słowniku zapożyczeń uwzględnia się także ekwiwalenty ortograficzne reprezentujące inne wariacje, nр. дабль-mpan / уубль-трап, джайлау / джейлау, дизассемблер /оисассемблер, сандвич / сэндвич. Przytoczone przykłady wariantów ortograficznych rzeczywiście wskazują na pewne trudności $\mathrm{w}$ procesie standaryzacji form językowych, których główna przyczyna wynika $\mathrm{z}$ braku restrykcyjnych zasad adaptacji fonetycznej. $\mathrm{Z}$ drugiej strony, kodyfikacja elementów wariantywnych jest żywym dowodem ewolucji języka, odzwierciedla wysokie tempo rozwoju społecznego.

Istotne jest także zagadnienie usankcjonowania normatywnego omawianych wcześniej wariantów graficznych, czyli jednostek zapożyczonych, które $\mathrm{w}$ tekstach pisanych funkcjonują $\mathrm{w}$ zapisie łacińskim oraz cyrylickim. Okazuje się bowiem, że w wielu najnowszych opracowaniach leksykograficznych właśnie takim dubletom poświęca się oddzielne rozdziały. Wprawdzie omawiany powyżej słownik ortograficzny nie rejestruje pożyczek angielskich $w$ ich oryginalnym zapisie, ale już $w$ innych pozycjach wydawniczych posiadających rangę słowników normatywnych takie właśnie ekwiwalenty graficzne mają swoje odrębne miejsce. Za przykład może posłużyć chociażby Толковый словарь русского языка начала XXI века. Актуальная лексика pod redakcją Galiny Sklarewskiej [Скляревская 2006]. Istnienie wtrętów w alfabecie łacińskim w historii języka rosyjskiego ma swoją wielowiekową już tradycję, jednak fakt kodyfikacji takich form i tym samym wpisanie ich do kanonu reguł poprawności językowej świadczy o sporym liberalizmie i elastyczności standardów współczesnej ruszczyzny.

\section{Podsumowanie}

Paralele ortograficzne oraz graficzne zapożyczeń angielskich zinwentaryzowane ze współczesnych mediów rosyjskich skłaniają do refleksji nad językiem i wytyczają kierunki w badaniach o charakterze normatywnym. 
Na podstawie powyższych rozważań można stwierdzić, że wariantywność (orto)graficzna w badanym dyskursie jest zjawiskiem powszechnym, a nawet można zaryzykować stwierdzenie - typowym dla innowacji leksykalnych o obcojęzycznej proweniencji. Niestabilność zgromadzonych przykładów anglicyzmów obserwuje się przede wszystkim w zapisie jednostek złożonych (pisownia łączna, rozdzielna lub z dywizem), w użyciu wielkiej i małej litery, pisowni podwójnych lub pojedynczych spółgłosek czy też w dowolności wyboru różnych samogłosek do oznaczenia tego samego fonemu angielskiego. Natomiast liczne warianty graficzne w prasie, czyli te same jednostki leksykalne zapisywane wymiennie łacinką lub cyrylicą, są w zasadzie cechą charakterystyczną współczesnego języka pisanego.

Jeśli chodzi o usankcjonowanie statusu omawianych wariantów przez normę językową, można postawić diagnozę, że norma ortograficzna stara się być restrykcyjna wobec zjawiska wariantywności i widać konsekwentne dążenia do eliminacji dubletów poprzez dopasowanie anglicyzmów do istniejących reguł poprawnej pisowni. Proces ten byłby zdecydowanie łatwiejszy, gdyby istniały odrębne zasady ortograficzne dla grupy jednostek obcego pochodzenia. Jednak mimo to uprawnieni leksykografowie standaryzują różne zapisy tego samego słowa poprzez umieszczanie dwojakich form w słownikach, poradnikach językowych i innych źródłach uznawanych społecznie za wzór poprawności językowej. Niemniej powyższe rozważania dowodzą, iż obecnej normy nie można uznać za kategoryczną, a raczej, jak zauważa Grażyna Sawicka [2011: 66], jest ona stosunkowo elastyczna i otwarta. Oznacza to, że współczesna norma ewoluuje i dość liberalnie odzwierciedla zmiany systemowe, które spowodowane są dynamicznym rozwojem rosyjskiego społeczeństwa.

\section{Bibliografia}

Валгина Н. С. 2003. Активные процессы в современном русском языке: Учебное пособие для студентов вузов, Москва: „Логос".

Горбачевич К. С. 1978. Нормы современного русского литературного языка. Пособие для учителей, Москва: „Просвещение”.

Скворцов Л. И., Шварцкопф Б. С. (red.) 1983. Литературная норма в лексике и фразеологии, Москва: „Наука”.

Bańko M., Hebal-Jezierska M. 2015. Wariacja graficzna w procesie adaptacji zapożyczeń, „Biuletyn Polskiego Towarzystwa Językoznawczego", z. LXXI, s. 141-152.

Bugajski M. 1993. Jezykoznawstwo normatywne, Warszawa: Wydawnictwo Naukowe PWN. Gajda S. 2000. Media - stylowy tygiel wspótczesnej polszczyzny, [w:] J. Bralczyk, K. Mosiołek-Kłosińska, Jezyk w mediach masowych, Warszawa: Upowszechnianie Nauki - Oświata „UN-O”, s. 19-27. 
Markowski A. 2005. Kultura języka polskiego. Teoria. Zagadnienia leksykalne, Warszawa: Wydawnictwo Naukowe PWN.

Sawicka G. 2011. W poszukiwaniu granic normy jezykowej i komunikacyjnej, [w:] A. Piotrowicz, M. Witaszek-Samborska, K. Skibski (red.), Norma jezykowa w aspekcie teoretycznym i praktycznym, Poznań: Wydawnictwo Poznańskiego Towarzystwa Przyjaciół Nauki, s. 57-67.

Smółkowa T. 2000. Nowe słownictwo w prasie, [w:] J. Bralczyk, K. Mosiołek-Kłosińska (red.), Jezzk w mediach masowych, Warszawa: Upowszechnianie Nauki - Oświata "UN-O”, s. 67-78.

\section{Źródła leksykograficzne}

Ахманова О. С. 2016. Словарь мингвистических терминов, Москва: Книжный дом „ЛИБРОКОМ".

Крысин Л. П. 2012. Современный словарь иностранных слов, Москва: АСТ-ПРЕСС КНИГА.

Лопатин В. В., Иванова О. Е. (red.) 2016. Русский орфографический словарь, около 200000 слов, Москва: АСТ-ПРЕСС КНИГА.

Скляревская Г. Н. 2006. Толковый словарь русского языка начала ХХІ века. Актуальная лексика, Москва: Эксмо.

Шагалова Е. Н. 2017. Словарь новейших иностранных слов, Москва: АСТ-ПРЕСС КНИГА. 
